\section{New record of a phasmid, Sipyloidea fontanesina Giglio-Tos, 1910 (Necrosciinae: Diapheromeridae) from Barnwapara, Chhattisgarh, India}

\author{
T.K. Mukherjee ${ }^{1}$, K.K. Banerjee ${ }^{2}$, B. Gupta ${ }^{2} \&$ \\ S. Mukherjee ${ }^{2}$ \\ 1,2 Postgraduate Department of Zoology, Presidency College, \\ $86 / 1$, College Street, Kolkata, West Bengal 700073, India \\ Email: ${ }^{1}$ mukherjee.tushar@redifmail.com
}

Phasmids belonging to the tribe Necrosciini (Subfamily Necrosciinae) are the most diverse and numerous among all other tribes under this subfamily. Many species are quite difficult to ascertain accurate systematics. The genus Sipyloidea contains seven species from India apart from two more species having doubtful occurrence from India. One seems to be Sipyloidea erechtheus (Westwood, 1859) recently collected from Karnataka (Murkul). The second species is Sipyloidea sipylus (Westwood, 1859) for which Brock (1995) mentioned that the specimens from India and Bangladesh are probably different species.

The original description of Sipyloidea fontanesina is brief and hence a detailed description is provided along with variations. Images 1-5 are provided here for better understanding of characteristics.

Material examined: 1 female, 15.iii.2009, (dry, forelegs missing), Barnwapara, Chhattisgarh, India, coll. Dr. K. Banerjee et al. PCEC-P1/2009, Entomology Laboratory

Date of publication (online): 26 June 2010

Date of publication (print): 26 June 2010

ISSN 0974-7907 (online) | 0974-7893 (print)

Editor: A.K. Hazra

Editor's Note: Although this record is based on a single specimen which is slightly damaged, the note is published due to the rarity of this species.

\section{Manuscript details:}

Ms \# 02338

Received 30 October 2009

Finally accepted 06 May 2010

Citation: Mukherjee, T.K., K.K. Banerjee, B. Gupta \& S. Mukherjee (2010). New record of a phasmid, Sipyloidea fontanesina Giglio-Tos, 1910 (Necrosciinae: Diapheromeridae) from Barnwapara, Chhattisgarh, India. Journal of Threatened Taxa 2(6): 978-979.

Copyright: () T.K. Mukherjee, K.K. Banerjee, B. Gupta \& S. Mukherjee 2010. Creative Commons Attribution 3.0 Unported License. JoTT allows unrestricted use of this article in any medium for non-profit purposes, reproduction and distribution by providing adequate credit to the authors and the source of publication.

Acknowledgements: The authors are thankful to the authorities of Presidency College, Kolkata for encouragement and laboratory facilities.

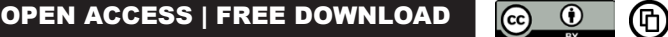

Collection, Presidency College, Kolkata.

Measurements (mm.): Total length 70; antennae 43; head 2.8x5 (length/width); pronotum 3x2 (length/ width); metazona13; metanotum 10; median segment 7; middle leg: femur 12, tibia 11, tarsi 5.5; hind leg: femur 17, tibia 14, tarsi 6.5; fore wing 6, hind wing 41.5 .

Description: Eyes black. Antennae long and slender, shorter than body, finely hairy, basal first segment thicker than second segment, rest filiform. Head nearly rectangular, longer than broad; blackish brown, with a median fine groove ending anteriorly in a minute $Y$ mark. Pronotum longer than broad, lateral margins parallel, with a median and a transverse fine groove, latter placed in front of middle, with scattered blackish patches. Mesonotum long with a raised median carina, entirely covered with minute smooth granules, and scattered blackish patches; on each side is an elongated narrow white patch that starts from near the middle of anterior half (left patch a little above the right patch) and posteriorly the patches fade away to ground colour of mesonotum. Ventrally the mesonotum is pale brown and feebly granulated; metanotum and median segment whitish-brown.

All legs rounded, smooth except for fine setae, with brown bands at intervals. Middle legs: femur and tibia, both dorsally and ventrally, with a distal blackish patch; dorsally the femur with extra feeble blackish bands. Tarsi dorsally blackish, ventrally black. Hind legs: femur with distal black patch, shorter than that on middle leg; this is more distinct dorsally than ventrally. Tibia black at distal half which is longer than that in middle tibia; this band is complete on the left leg and on the right leg, there is a small distinct distal portion which is not black.

Fore-wing more or less rectangular than ovalelongated, apex conical; opaque, costal area reticulated with dirty spots; Sc whitish, radial vein strong and black; cubitus is the only branched vein; anterior branch of cubitus closely approximates radial vein. Remaining areas of the fore wing have a few parallel transverse veinlets. Long veins distally deep brown.

Hind wings transparent, pointed at apex; costal and radial areas as a whole brownish. Costal and subcostal areas reticulated at a small area near base; at the other areas there are transverse cross veins; cells with brownish patch are seen near basal of costal area. All long veins with black marks at intervals.

Second, third and fourth abdominal segments ventrally gradually brownish, fourth being brownish-black; the rest of the segments (ventrally) paler to whitish. Apex of anal segment triangularly divided. Operculum carinated, pointed at apex; does not reach apex of last segment.

Distribution:India:West Bengal (Kolkata); Chhattisgarh (Barnwapara) 


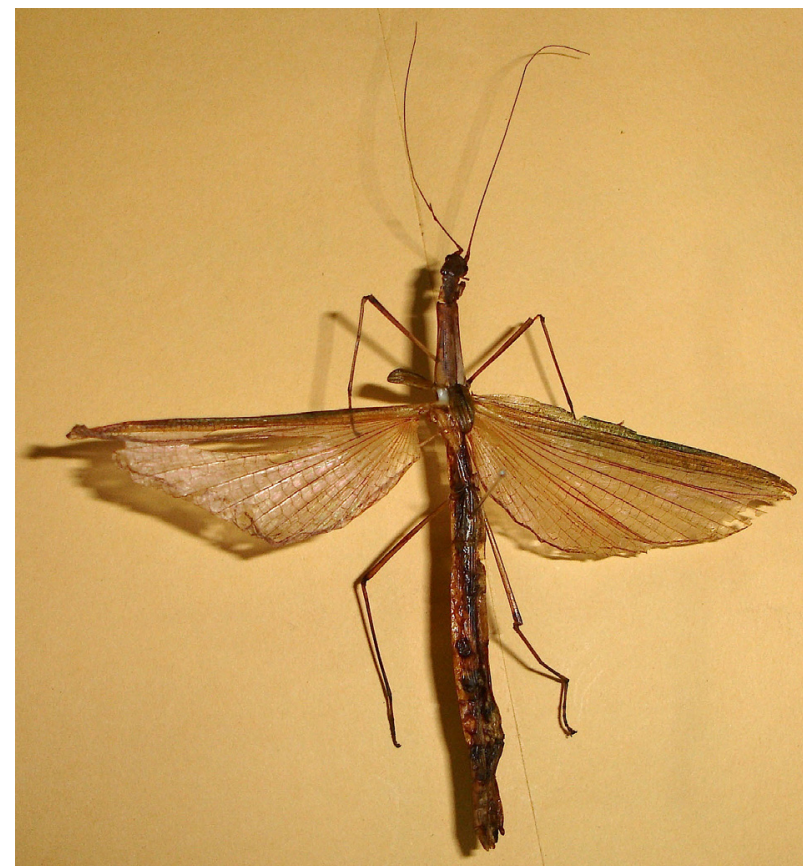

Image 1. Entire specimen (female).

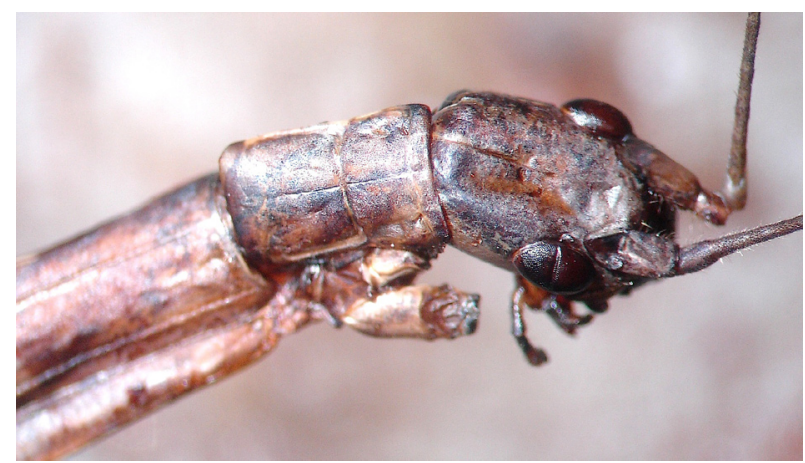

Image 2. Dorsal view of head, prothorax and part of mesothorax.

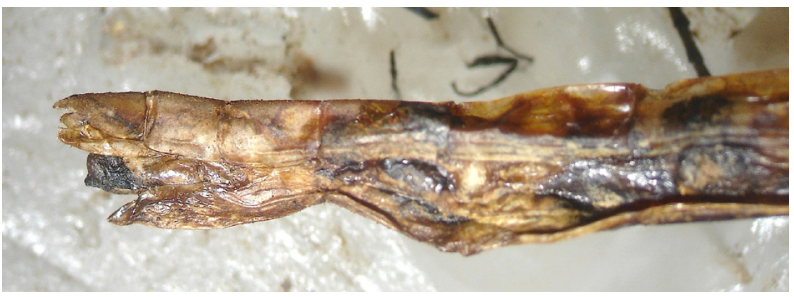

Image 3. End of abdomen showing anal segment and operculum.

\section{Discussion}

This species was first recorded from Kolkata (Calcutta) by Giglio-Tos (1910) and there seems to be no further record after the discovery. The specimen is smaller than that recorded by Giglio-Tos (1910), paler than the typical specimen in Museo Regionale di Scienze Naturali, Torino (MRSN). Other variations from published accounts are: (i) mesonotum entirely covered by minute smooth granules

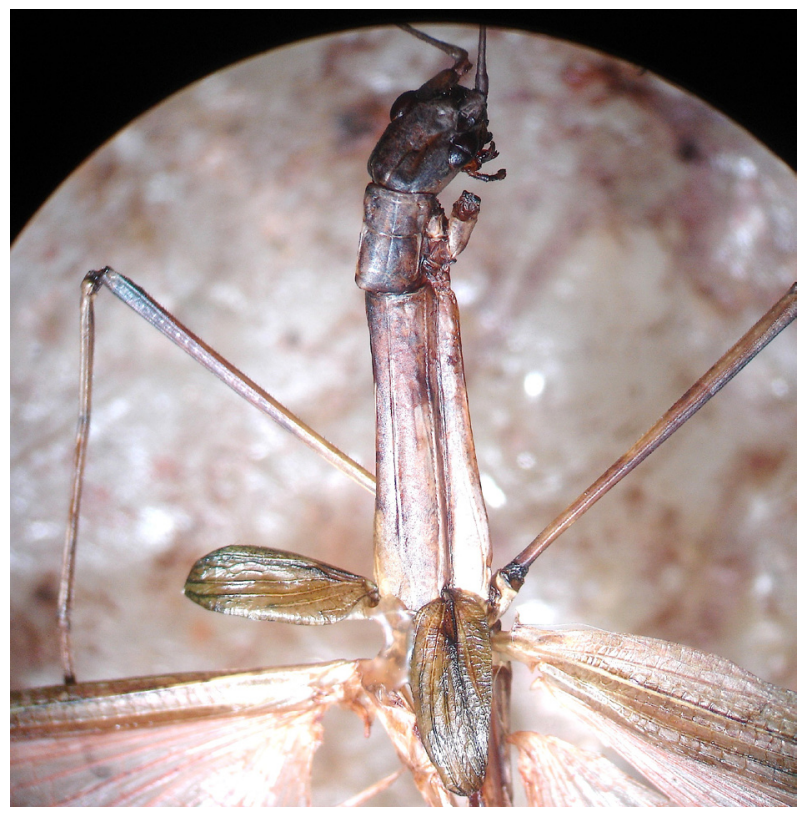

Image 4. Forewing.

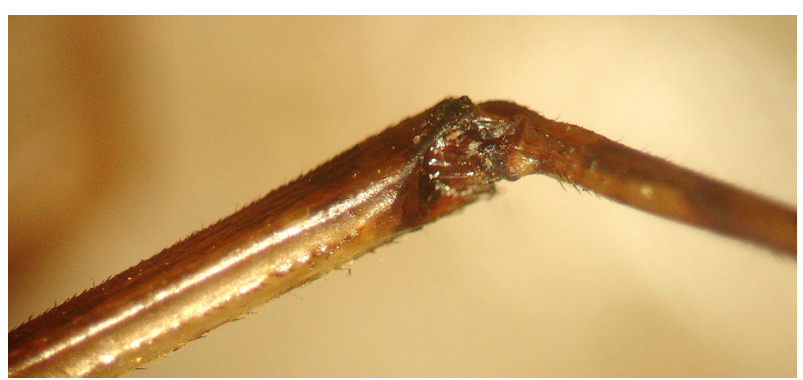

Image 5. Hind femur-tibial junction.

and scattered blackish patches and also an elongated narrow white patch on each side, (ii) in forewing, radial vein strong and black and without black-spots in middle, (iii) in hindwing, costal and radial areas as a whole are more brownish than the posterior area which is uniformly but less brownish, not white; all long veins with black marks at intervals.

\section{REFERENCES}

Brock, P.D. (1995). Catalog of Malaysian species. Malayan Nature Journal 49: 92.

Brock, P.D. 1998 (1997). Catalogue of stick-insect (Insecta: Phasmida) type material in the Museo Regionale di Scienze Naturali, Torino. Bollettino del Museo Regionale di Scienze Naturali, Torino 15(2): 305.

Giglio-Tos, E. (1910). Fasmidi esotici del R. Museo zoologico di Torino e del Museo civico di Storia naturale di Genova. Bollettino dei Musei di Zoologia ed Anatomia comparata della Royal Università di Torino 25(625): 53.

Otte, D. \& P.D. Brock (2005). Phasmida Species File. Catalog of Stick and Leaf Insects of the World. The Insect Diversity Association at the Academy of Natural Sciences, Philadelphia, 318pp.

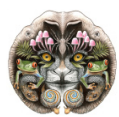

